\title{
RHETORICAL APPROACH OF FLAVIUS CLAUDIUS JULIAN'S LETTERS
}

\author{
George Alexandropoulos \\ University of Athens
}

\begin{abstract}
This study examines the rhetorical practice of two rhetorical letters ${ }^{1}$ (Letter to Themistius the philosopher and Letter to the Senate and the People of Athens) written by Flavius Claudius Julian ${ }^{2}$ the emperor. Its purpose is to describe the way that Julian organizes the texts' coherence and intertextuality and draw conclusions about the text, the context of the letters and Julian's political character.
\end{abstract}

\section{INTRODUCTION}

Julian in an attempt to find supporters and legitimize his political ideology writes to the Athenians as they have a broad knowledge of their forefathers' philophical and political background. It was written in Illyricum in 361, when Julian was on the march against Constantius, and is the chief authority for the events that led to his elevation to the Imperial rank. Julian writes to the Athenians of the fourth Christian century as though they still possessed the influence and standards of their forefathers. He was well known at Athens, where he had studied before his elevation to the Caesarship and he was anxious to clear himself in the eyes of the citizens. For the first time he ventures to speak the truth about Constantius and to describe the latter's ruthless treatment of his family (Wright 1998: 241). His main purpose is to promote himself defining the opponent's negative qualities.

On the strength of his Aristotelian "Paraphrases" Themistius may be called a scholar, though hardly a philosopher as he himself claimed. Technically he was a Sophist: that is to say he gave public lectures ( $\dot{\pi} \pi \delta \varepsilon \dot{\xi} \xi \varepsilon 1 \zeta)$, wrote exercises after the Sophistic pattern and went on embassies, which were entrusted to him solely on account of his persuasive charm. But he insisted that he was no Sophist, because he took no fees and styled himself a practical philosopher. He was indifferent to the Neo-Platonic philosophy, and, since Constantius made him a Senator, he cannot have betrayed any zeal for the Pagan religion. From Julian's Pagan restoration he

\footnotetext{
${ }^{1}$ For the text of these letters see Wright (1998).

2 For more information about his life see Athanassiadi (1992), Baker-Brian \& Tougher (2012), Bouffartigue (1992), Fouquet (1985), Smith (1995), Tougher (2007).
} 
seems to have held aloof, and, though Julian had been his pupil, probably at Nicomedia, he did not appoint him to any office. Under the Christian Emperor Theodosius he held a prefecture. There is no evidence for a positive coolness, such as Zeller assumes, between Themistius and Julian, and we know too little of their relations to assert with some critics that the respectful tone of this letter is ironical. It was probably written after Julian had become Emperor, though there is nothing in it that would not suit an earlier date; it is sometimes assigned to when Julian was still Caesar. The quotations from Aristotle are appropriately addressed to Themistius as an Aristotelian commentator (Wright 1998: 200-201). In the second letter, we see a different Julian who seems to have lost his confidence even though he gained the throne and became emperor; he may feel embarrassed as he must fulfill his duties and change the social and political situation in the Empire.

In the present paper, the rhetorical ${ }^{3}$ practice of these letters is going to be examined by adopting some models. Julian's political letters will be examined according to lines of discourse analysis as language practice proposed by Fairclough (1992:78-87), which are: a) the force of speech, (ex. speech acts to persuade, to denounce, to compliment etc.), b) the coherence ${ }^{4}$ of the text (ex. rhetorical relations) and c) intertextuality ${ }^{5}$, namely the incorporation of other texts in each letter.

The coherence of Julian's letters will be analyzed through the Mann \& Thompson Rhetorical Structure Theory (1988), in order to draw conclusions about the communicative goal of these letters. For this reason, Hymes (1974) context theoretical model and Searle's categorization ${ }^{6}$ (1969; 1979; 1994;

\footnotetext{
${ }^{3}$ For rhetorical practice in Byzantium see Hunger (1978).

${ }^{4}$ For more information about coherence see de Beaugrande \& Dressler (1981), Mann \& Thompson (1986 1988), Hoey (1993) and Winter (1977). Mann and Thompson $(1986 \cdot 1988)$ and Mann et al. (1992) propose some rhetorical relations (circumstances, solutionhood, elaboration, cause, result, purpose, condition, interpretation, evaluation, restatement, summary, sequence, contrast, motivation, antithesis, background, enablement, evidence, justify, concession, joint) expressed in any kind of text. These relations can describe the speakers' rhetorical organization in a different way, as the Rhetorical Structure Theory can focus on the rhetorical goal of the text combining the total of its relations. These relations are divided into two spans: nucleus and satellite or nucleus and nucleus. The role of the context and the speech acts can also play important role in the interpretation of the choice of the certain rhetorical relations in each text. The functions of these rhetorical relations are a product of the speaker's intentionality and give the opportunity to the hearer to discover how the parts of this text can be combined with each other for a certain purpose.

${ }^{5}$ For more information about intertextuality see de Beaugrande \& Dressler (1981), Bakhtin (1981·1986•1993), Kristeva (1980), Riffaterre (1978·1983·1990).

${ }^{6}$ For Searle $(1969 ; 1979 ; 1994 ; 1996 a$, b) we have assertive speech acts: speech acts that commit a speaker to the truth of the expressed proposition, directive speech acts: speech acts that are to cause the hearer to take a particular action, commissive speech
} 
1996a, b) about speech acts are adopted. For the study of intertextuality through an approach of Critical Discourse Analysis ${ }^{7}$ the Discourse Representation proposed by Fairclough (1992), Caldas-Coulthard (1997) and Alexandropoulos (2012) models are adopted in order to find the new functions that texts acquire when they are incorporated into the new texts. The above methodology is going to give us the opportunity to draw some conclusions about the way that Julian uses his speech in order to achieve his communicative goal, to persuade and legitimize his choices until then.

\section{COHERENCE: RHETORICAL RELATIONS}

Julian as a political speaker organises his political thought in a certain way in order to persuade and create political groups that will follow him. In this study we concetrate on some rhetorical relations that contribute to Julian's communicative goal and express his ideology.

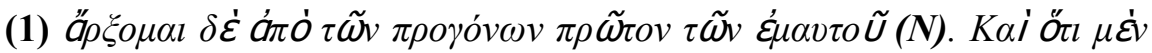

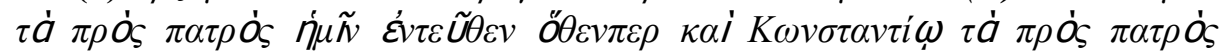

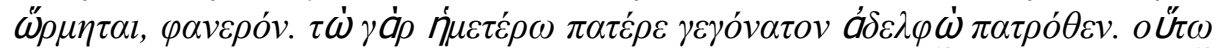

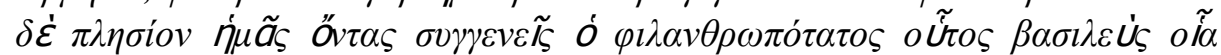

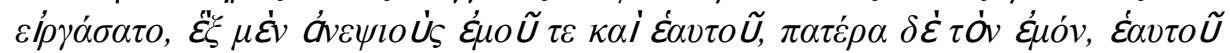



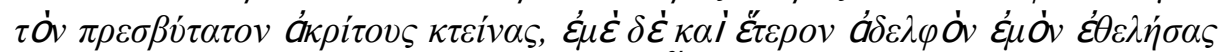

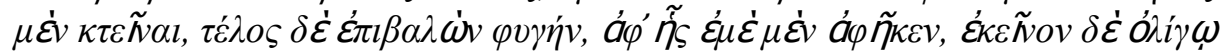

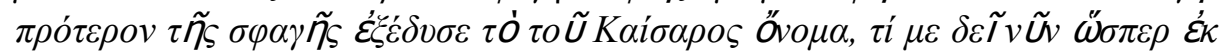

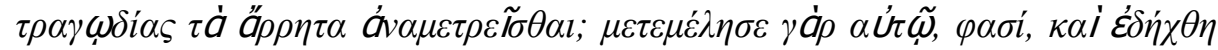

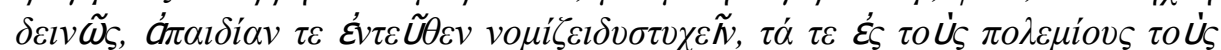

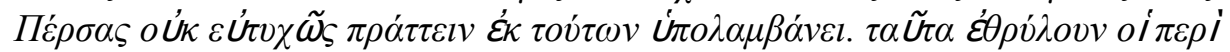



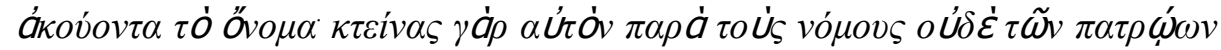

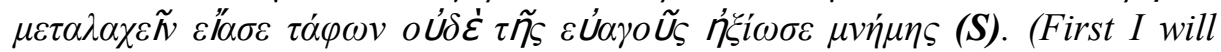
begin with my ancestors $(\mathrm{N})$. That on the father's side I am descended from the same stock as Constantius on his father's side is well known. Our fathers were brothers, sons of the same father. And close kinsmen as we were, how this most humane Emperor treated us! Six of my cousins and his, and my father who was his own uncle and also another uncle of both of us on the

acts: speech acts that commit a speaker to some future action, expressive speech acts: speech acts that express the speaker's attitudes and emotions towards the proposition and declarations: speech acts that change the reality in accord with the proposition of the declaration.

${ }^{7}$ For Critical Discourse Analysis see van Dijk (1999-2001), Fairclough (1992·2000), Fairclough \& Wodak (1997). 
father's side, and my eldest brother, he put to death without a trial; and as for me and my other brother, he intended to put us to death but finally inflicted exile upon us; and from that exile he released me, but him he stripped of the title of Caesar just before he murdered him. But why should I "recount," as though from some tragedy, "all these unspeakable horrors?" For he has repented, I am told, and is stung by remorse; and he thinks that his unhappy state of childlessness is due to those deeds, and his ill success in the Persian war he also ascribes to that cause. This at least was the gossip of the court at the time and of those who were about the person of my brother Gallus of blessed memory, who is now for the first time so styled. For after putting him to death in defiance of the laws he neither suffered him to share the tombs of his ancestors nor granted him a pious memory (S).)

(Letter to the Senate and the People of Athens 270c-271a)

In example (1) Julian uses the rhetorical relation of the elaboration ${ }^{8}$. In the

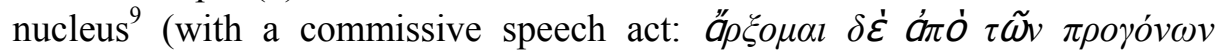

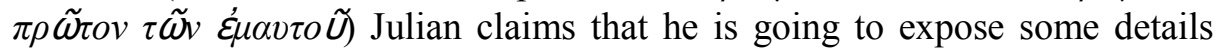
about his origins. Even though his origin is known to the Senate and the People of Athens, he reminds them of some elements in order to take them in consideration and keep them in their mind during his speech. In the satellite ${ }^{10}$ Julian exposes some details about the way that Constantius behaved to him in the past. We actually note that Julian uses the repetition of some words such as $\pi \alpha \tau \rho \dot{\alpha}, \pi \alpha \tau \dot{\varepsilon} \rho \varepsilon, \pi \alpha \tau \rho \dot{\theta} \theta \varepsilon v, \theta \varepsilon \tilde{l} v$ etc, as he wants to give emphasis to his relationship with Constantius. Besides this, he tries to give emphasis on the negative aspects of Constantius' character as he killed a lot of relatives, among them Julian's father, in order to gain the throne. Julian reveals through the

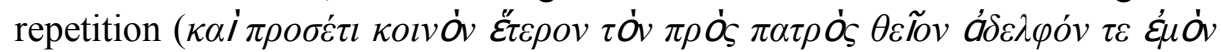

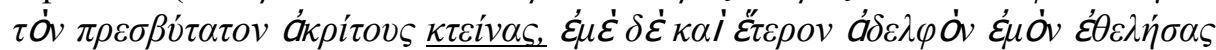
$\mu \dot{\varepsilon} \underline{\kappa \tau \varepsilon \tilde{N} \alpha l}$ ) Constantius' plan about his murder. He also uses irony with an adjective of evaluative character in superlative degree ( $\dot{O} \varphi \imath \lambda \alpha v \theta \rho \omega \pi \delta$ t $\alpha \tau \sigma \varsigma$ $o$ i̛to $\beta \alpha \sigma i \lambda \varepsilon \dot{U} \varsigma)$ as he wants to castigate Constantius' behaviour. Julian



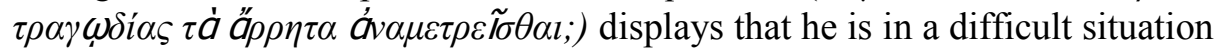
and does not know how to deal with what happened to him. As a consequence, it could be said that this relation is used by the rhetorical producer as a background to public mind for his following argumentations and operates in a supportive way for Julian's promotion; it seems that giving emphasis on negative qualities of his opponent, he gives emphasis on his

\footnotetext{
${ }^{8}$ In the rhetorical relation of elaboration the nucleus give us basic information and the satellite additional information.

${ }^{9}$ Nucleus (N) is the more central span in a text.

${ }^{10}$ Satellite $(\mathrm{S})$ is the less central one in a text.
} 
positive character qualities, such as the magnanimity and respect to political hierarchy.

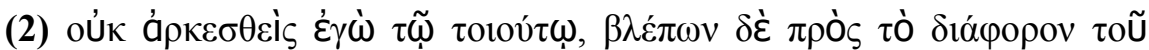

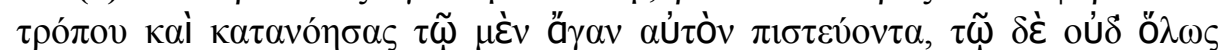

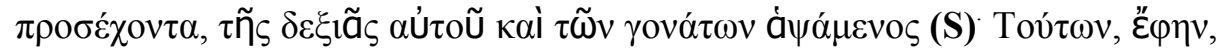

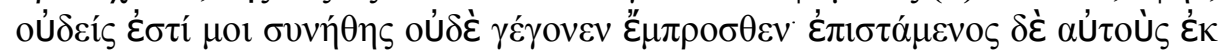

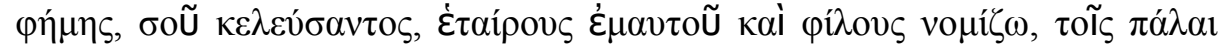

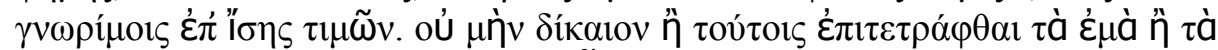

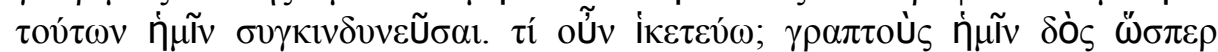

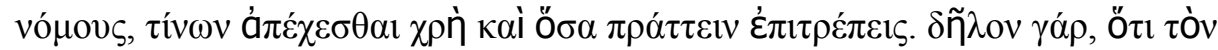

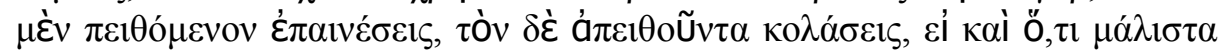

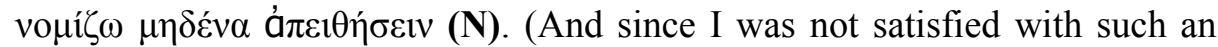
arrangement and saw how his manner to them varied, for I observed that he trusted one of them too much and paid no attention at all to the other (S), I clasped his right hand and his knees and said: "I have no acquaintance with any of these men nor have had in the past. But I know them by report, and since you bid me I regard them as my comrades and friends and pay them as much respect as I would to old acquaintances. Nevertheless it is not just that my affair's should be entrusted to them or that their fortunes should be hazarded with mine. What then is my petition? Give me some sort of written rules as to what I must avoid and what you entrust to me to perform. For it is clear that you will approve of him who obeys you and punish him who is disobedient, though indeed I am very sure that no one will disobey you (N).”)

(Letter to the Senate and the People of Athens 282ab)

In the above example Julian uses the rhetorical relation of justification ${ }^{11}$ as to explain the reasons that lead him to do certain things concerning empire strategy. As Julian could not trust anyone of the officers that Constantius gave to him, he decided to ask for certain orders so as to avoid any kind of rumours from detractors. In the nucleus Julian uses representative speech acts through the causative particles (o $U^{\prime} \kappa a^{\prime} \rho \kappa \varepsilon \sigma \theta \varepsilon \dot{\xi}$ and $\kappa \alpha \tau \alpha v o ́ \eta \sigma \alpha \varsigma$ ) so as to summarize the reasons (mostly Constantius' changeability) that lead him to do what he describes in the nucleus. The nucleus with direct speech gives all the information about what he did; in this part of discourse he uses mostly

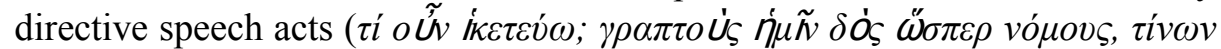


do what he wants. The direct speech ${ }^{12}$ dramatizes the situation and operates as

\footnotetext{
${ }^{11}$ In the nucleus of this relation we have the basic text and in the satellite we have some information supporting the writer's right to express the previous part of a text.

12 For more functions about the use of direct speech see Mayes (1990), Holt (19962000).
} 
evidence for the persuasiveness of Julian's assertions. Last but not least, it is also worth mentioning that Julian uses this rhetorical relation as a means to promote himself and give emphasis on his character's positive aspects. In this way, we inform that Constantius has changeability in his decisions instead of Julian who has certain goals, has self-awareness, respects political hierarchy and cares about the empire.

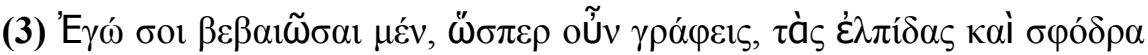

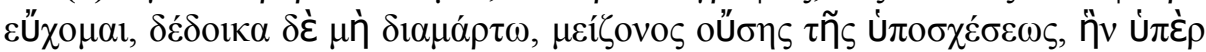

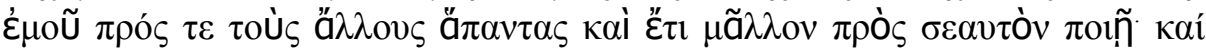

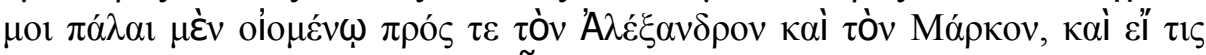

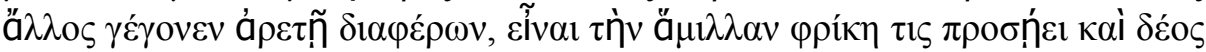

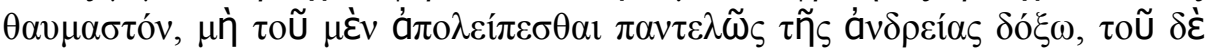

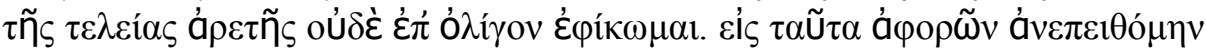

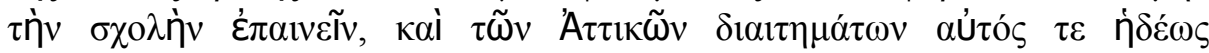

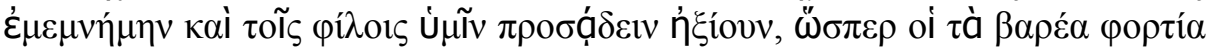

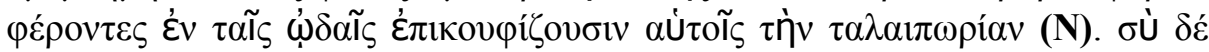

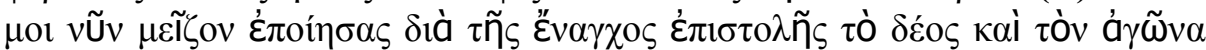

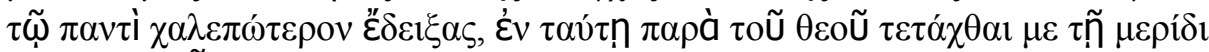



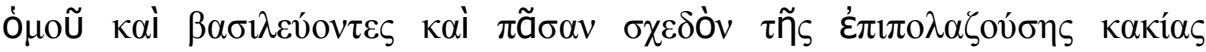

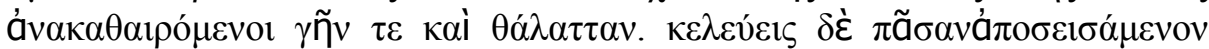

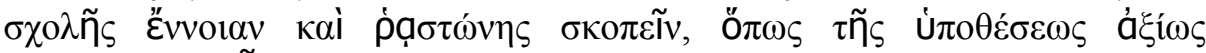

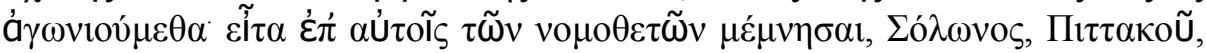

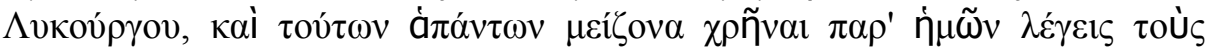

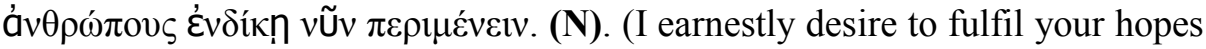
of me even as you express them in your letter, but I am afraid I shall fall short of them, since the expectations you have raised both in the minds of others, and still more in your own, are beyond my powers. There was a time when I believed that I ought to try to rival men who have been most distinguished for excellence, Alexander, for instance, or Marcus; but I shivered at the thought and was seized with terror lest I should fail entirely to come up to the courage of the former, and should not make even the least approach to the latter's perfect virtue. With this in mind I convinced myself that I preferred a life of leisure, and I both gladly recalled the Attic manner of living, and thought myself to be in sweet accord with you who are my friends, just as those who carry heavy burdens lighten their labour by singing $(\mathbf{N})$. But by your recent letter you have increased my fears, and you point to an enterprise in every way more difficult. You say that God has placed me in the same position as Heracles and Dionysus of old who, being at once philosophers and kings, purged almost the whole earth and sea of the evils that infested them. You bid me shake off all thought of leisure and inactivity that I may prove to be a good soldier worthy of so high a destiny $(\mathbf{N})$.) 


\section{(Letter to Themistius the philosopher 253a-254a)}

In this certain example Julian uses the rhetorical relation of contrast ${ }^{13}$ and through this tries to compare his opinion with Themistius' thought. Actually, Julian mentions that it is very difficult to fulfill his duties as he prefers more a life of leisure than political responsibilities. But Themistius has a different opinion as he supports that Julian ought to obey Gods because they granted him the same position as Heracles and Dionyssus. This parallelism gives more emphasis to Julian's duties. His opinion is expressed through the first person's personal pronoun $(\dot{\xi}, \dot{\omega})$ istead of Themistius thought which is expressed with the second person's personal pronoun $\left(\sigma \iota^{\prime}\right)$. Using this relation at the beginning of his speech Julian as a political producer tries to express his different thought as a background of his next argumentation. His political thought resorts to the above rhetorical organization as he wants to promote the Gods' role. Mainly, in the next example number (4) the rhetorical relation of antithesis ${ }^{14}$ interprates Julian's rhetorical practice.

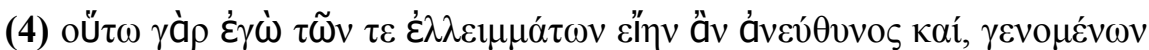

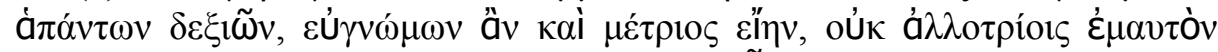

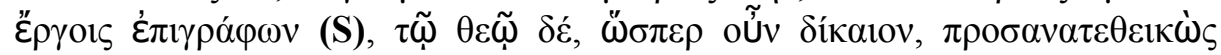

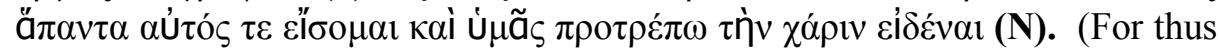
I shall be free from responsibility for my shortcomings, and if everything turns out favourably I shall be discreet and moderate, not putting my name to the deeds of other men (S), but by giving God the glory for all, as it is right, it is to Him that I shall myself feel gratitude and I urge all of you to feel the same (N).)

\section{(Letter to Themistius the philosopher 267b)}

It seems that Julian knows very well what he wants to say from the beginning his speech and for this reason example (3) operates as a background of his rhetorical structure. In example (3) the supplanting and undermining of political ego is achieved through the relation of antithesis. This time the political ego does not compare with other entities, but gives its place to Gods. Julian sets gods in the nucleus as he wants to promote them as the only support for the empire's fortune. Through the certain relations (contrast and antithesis) Julian promotes himself as a personality who does not have ambitions and takes the gods into consideration before everything he does. In this way Julian as a text producer shows that he respects gods and his political mission can be relied only on them.

\footnotetext{
${ }^{13}$ In this rhetorical relation we have two alternative views compared in both nuclei.

${ }^{14}$ In this relation we have ideas favored by the author in the satellite and ideas disfavored by the author in the nucleus.
} 
After the above analysis in Julian's letters we can draw some conclusions about the way he organizes his speech because of his political and ideological intentionality. In examples (1) and (2) Julian uses the rhetorical relations of elaboration and justification and in the examples (3) and (4) uses the rhetorical relations of contrast and antithesis. These relations give him the ability to promote his ideas because of their argumentative character. In the Letter to the Senate and the People of Athens he uses the relations of elaboration and justification as he must persuade them that the basic opponent of his political ideology is Constantius, as he is a hazardous and criminal personality. In the Letter to Themistius the philosopher the rhetorical relations of contrast and antithesis operate as a means for showing his different way of thinking about the fact that he is the emperor of the Byzantine empire and he must fulfill his duties coming up to public expectations.

Analyzing these letters, we realize that even though Julian wanted to gain the throne and become emperor, when he made it, he could not believe that there are no enemies anymore and his only enemy is he himself as it was going to be proven in the route of history. It was the psychological instability that made him intolerant with everything that could not be compatible with his opinion.

\section{INTERTEXTUALITY}

At this point, the way that intertextualistic sources are included into Julian's letters is going to be examined in order to define their new rhetorical functions.

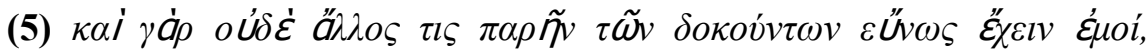

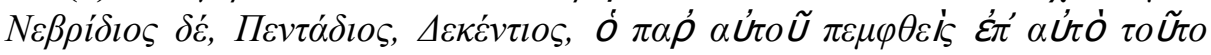

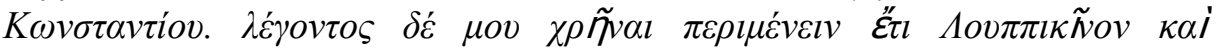



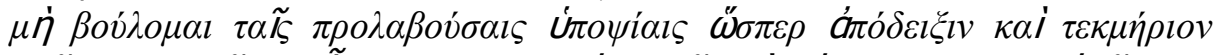

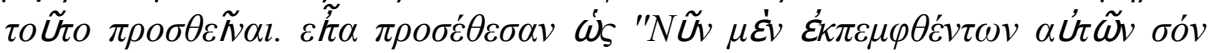

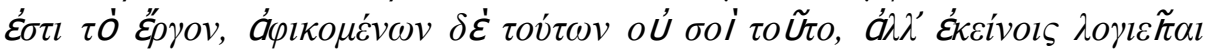

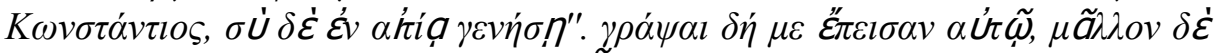



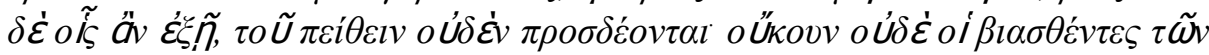

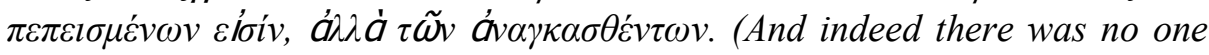
there belonging to the party supposed to be friendly to me, but only Nebridius, Pentadius, and Decentius, the latter of whom had been despatched for this very purpose by Constantius. And when I replied that we ought to wait still longer for Lupicinus and Florentius, no one listened to me, but they all declared that we ought to do the very opposite, unless I wished to add this further proof and evidence for the suspicions that were already entertained 
about me. And they added this argument: "If you send away the troops now it will be regarded as your measure, but when the others come Constantius will give them not you the credit and you will be held to blame." And so they persuaded or rather compelled me to write to him. For he alone may be said to be persuaded who has the power to refuse, but those who can use force have no need to persuade as well; then again where force is used there is no persuasion, but a man is the victim of necessity.)

(Letter to the Senate and the People of Athens 283c - 283d)

In this example, Julian tries to persuade the Senate and the People of Athens that everything he did was after the soldiers' urge. In this way it could

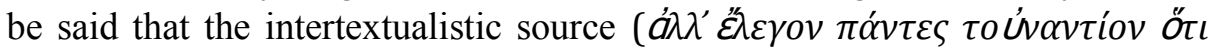

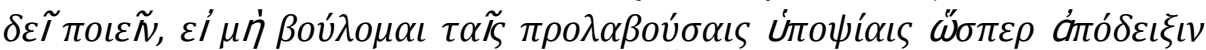

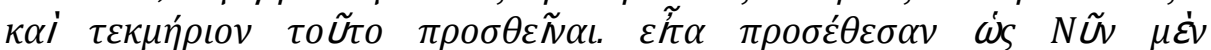




as a background to Julian's argumentation. Julian incorporates the intertextualistic source in both ways; either with indirect speech (ötı $\delta \varepsilon \tilde{I}$

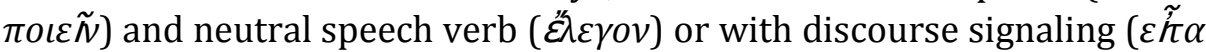

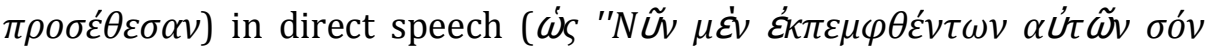

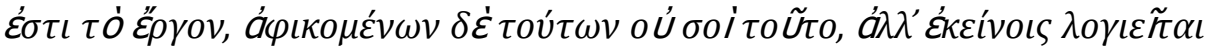

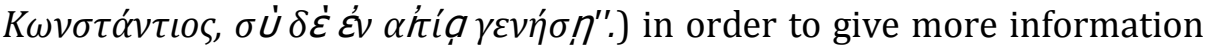
about the soldiers' additional argumentation as it gives information about what Julian passed through in Galatia and in Milan and legitimizes every decision he made trying to find a solution to strategy problems.

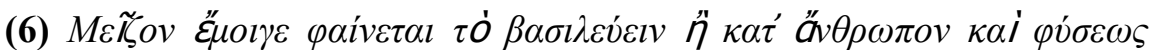



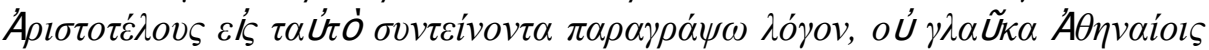

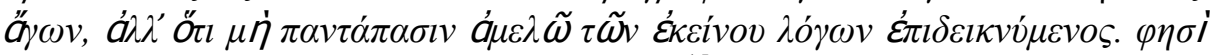

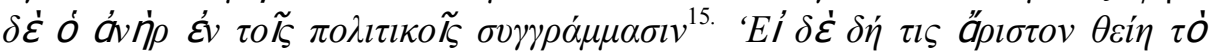

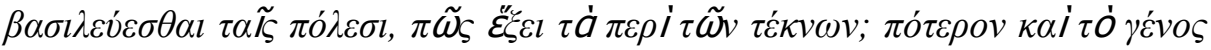

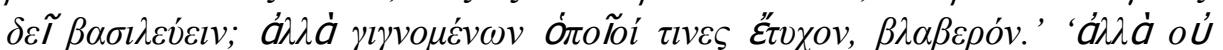

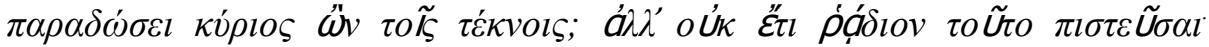

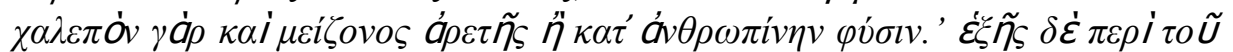

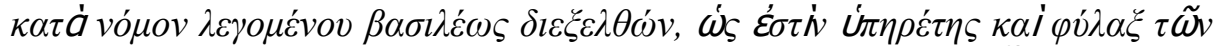

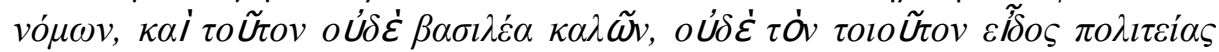

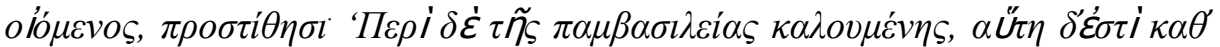

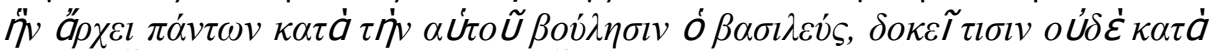

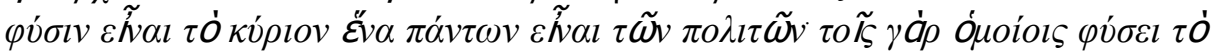

${ }^{15}$ Aristotle, Politics 3.15. 1286b-1287a. 


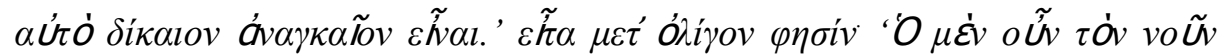

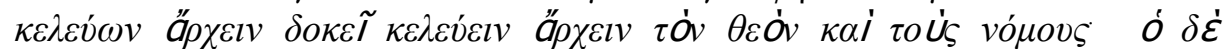

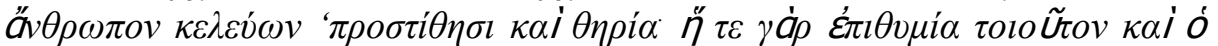

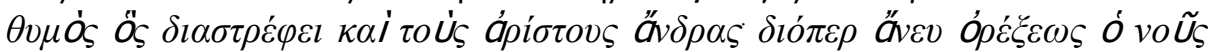

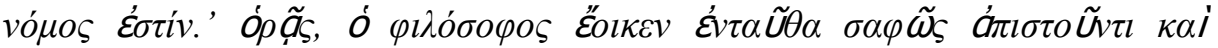

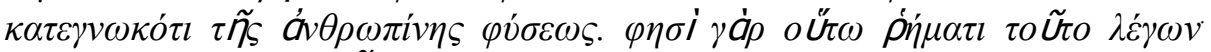

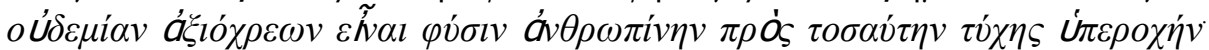

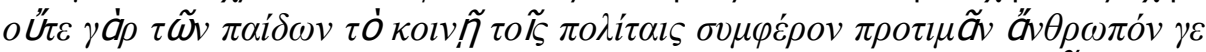

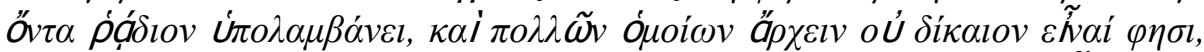

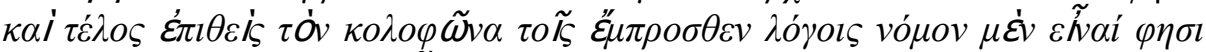

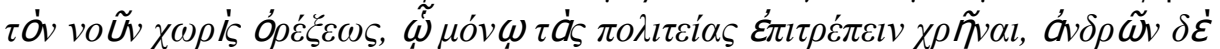

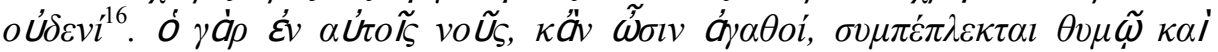

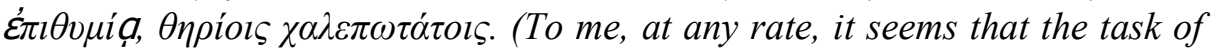
reigning is beyond human powers, and that a king needs a more divine character, as indeed Plato too used to say. And now I will write out an excerpt from Aristotle to the same effect, not "bringing owls to the Athenians," but in order to show you that I do not entirely neglect his writings. In his political treatises he says: "Now even if one maintain the principle that it is best for cities to be governed by a king, how will it be about his children? Ought his children to succeed him? And yet if they prove to be no better than anybody else, that would be a bad thing for the city. But you may say, though he has the power he will not leave the succession to his children? It is difficult indeed to believe that he will not; for that would be too hard for him, and demands a virtue greater than belongs to human nature." And later on, when he is describing a so-called king who rules according to law, and says that he is both the servant and guardian of the laws, he does not call him a king at all, nor does he consider such a king as a distinct form of government; and he goes on to say: "Now as for what is called absolute monarchy, that is to say, when a king governs all other men according to his own will, some people think that it is not in accordance with the nature of things for one man to have absolute authority over all the citizens; since those who are by nature equal must necessarily have the same rights." Again, a little later he says: "It seems, therefore, that he who bids Reason rule is really preferring the rule of God and the laws, but he who bids man rule, adds an element of the beast. For desire is a wild beast, and passion which warps even the best men. It follows, therefore, that law is Reason exempt from desire." You see the philosopher seems here clearly to distrust and condemn human nature. For he says so in so many words when he asserts that human nature is in no case worthy of such an excess of fortune. For he thinks that it is too hard for one who is merely human to prefer the general weal of the citizens to his own children; he says that it is not just that one man should rule over

${ }^{16}$ Cf. Plato, Theatetus 153. 
many who are his equals; and, finally, he puts the finishing stroke to what he has just said when he asserts that "law is Reason exempt from desire," and that political affairs ought to be entrusted to Reason alone, and not to any individual man whatever. For the reason that is in men, however good they may be, is entangled with passion and desire, those most ferocious monsters.)

(Letter to Themistius the philosopher 260c-261d)

Julian in this certain example appeals to Aristotle in order to prove his thought is right. Mainly, he puts the text from Aristotle into quotation giving the impression that he is of an honest character and he does not change Plato's speech; in this way Julian ensures the objectivity and the ability to prove. This intertextualistic source supports Julian's assertion about the way of governing. The quoting marks are combined with an assertive speech verb so as to interpret the intertextualistic source and display that the first person speaking appears to express his degree of conviction as far as the truth of his words is concerned. Lastly, it is obvious that Julian also uses the discourse signaling $(\pi \rho o \sigma \tau i \theta \eta \sigma l)$ in order to define the position of the intertextualistic source in relation to other parts that follow.

In general the incorporation of intertextualistic sources into two letters serves operations, such as background and proof. It was noted that Julian prefers more the neutral and assertive speech verbs in both letters. His goal in the Letter to the Senate and the People of Athens is to persuade them, legitimize his choices and create social and political groups that will follow them. Through the intertextualistic sources in his letter to Themistius, he tries to prove that he has a wide knowledge and prove everything he says.

\section{CONCLUSION}

To sum up, after studying the rhetorical relations in macrostructure and the intertextualistic sources it is clearly seen that text and context interact with each other and have favourable effects on the public. The main purpose of these letters is to serve the text producer's goal: persuasion and emphasizing on his positive aspects as a means of legitimizing his political choices. His ideological intentionality defines how he organizes his thought in order to promote himself and cause harm to everyone who subverts and opposes him. Speech acts, rhetorical relations and recontextualized, intertextualistic sources are united to the orator's benefit. Two letters with different content and different rhetorical relations and intertextualistic operations support a common goal, to promote Julian as an emperor who strives for public wellfare, has self-awareness and is not arrogant. 


\section{REFERENCES}

Alexandropoulos, G. (2012). Text and context in Flavius Claudius Julian's political speeches: coherence, intertextuality and communicative goal. $\mathrm{PhD}$ Thesis. University of Athens.

Athanassiadi, P. (1992). Julian: an intellectual biography. London: Routledge.

Bakhtin, M. (1981). Discourse in the Novel. In: Holquist, M. (ed.), The Dialogic Imagination. Austin: University of Texas Press.

Bakhtin, M. (1986). Speech Genres and Other Late Essays. (Trans. by Vern W. McGee). Austin: University of Texas Press.

Bakhtin, M. (1993). Toward a Philosophy of the Act. (Ed. V. Liapunov and M. Holquist. Trans. Vadim Liapunov). Austin: University of Texas Press.

Baker-Brian, N. \& S. Tougher (2012). Emperor and Author: The Writings of Julian the Apostate. Swansea: Classical Press of Wales.

de Beaugrande, R. \& W. Dressler (1981). Introduction to Textlinguistics. London: Longman.

Bouffartigue, J. (1992). L'empereur Julien et la culture de son temps. Collection des Études Augustiniennes. Série Antiquité 133.

Caldas-Coulthard, C. R. (1997). News as Social Practice: A Study in Critical Discourse Analysis. Florianopolis: Advanced Research in English Series.

van Dijk, T. A. (1999). Towards a Theory of Context and Experience Models in Discourse Processing. In: van Oostendorp, H. \& S. Goldman (eds.), The Construction of Mental Representations during Reading. Hillsdale, NJ: Erlbaum, 123-48.

van Dijk, T. A. (2001). Discourse, Ideology and Context. Folia Linguistica XXX (1-2): 11-40.

Fairclough, N. (1992). Discourse and social change. Cambridge: Polity Press.

Fairclough, N. (2000). Discourse, social theory, and social research: the discourse of

welfare reform. Journal of Sociolinguistics 4 (2): 163-195.

Fairclough, N. \& Wodak, R. (1997). Critical discourse Analysis. In: van Dijk T. A. (ed.), Discourse as Social Interaction. London: Sage Publications, 258-284.

Fouquet, C. (1985). Julien, la mort du monde antique. Paris: Belles Lettres.

Hoey, M. (1993). A common signal in discourse: how the word "reason" is used in Texts. In: Sinclair, J. M., G. Fox \& M. Hoey (eds.), Techniques of Description in Spoken and Written Discourse: A Tribute to Malcolm Coulthard. Taylor \& Francis, London.

Holt, E. (1996). Reporting on Talk: The Use of Direct Reported Speech in Conversation. In Research on Language and Social Interaction 29 (3): 219-245. 
Holt, E. (2000). Reporting on Reacting: Concurrent Responses to Reported Speech. In Research on Language and Social Interaction 33(4): 425-454.

Hunger, H. (1978). Die hochsprachliche profane Literatur der Byzantiner. Munchen: Beck.

Hymes, D. (1974). Foundations of Sociolinguistics: An Ethnographic Approach. Philadelphia: University of Pennsylvania Press.

Kristeva, J. (1980). Desire in Language. Oxford: Basil Blackwell.

Linell, P. (1998). Discourse across boundaries: on recontextualizations and the blending of voices in professional discourse. Text 18 (2): 143-157.

Mann, W. C. \& S. A. Thompson (1986). Relational propositions in discourse. Discourse Processes 9 (1): $57-90$.

Mann, W. C. \& S. A. Thompson (1988). Rhetorical Structure Theory: towards a functional theory of text organization. Text 8 (3): $243-281$.

Mayes, P. (1990). Quotation in spoken English. In Studies in Language 14(2): 325-363.

Riffaterre, M. (1978). Semiotics of Poetry. Bloomington \& London: Indiana University Press.

Riffaterre, M. (1983). Text Production. New York: Columbia University Press.

Riffaterre, M. (1990). Compulsory Reader Response: The Intertextual Drive. In: Worton, M. \& Still, J. (eds.), Intertextuality: Theories and Practices. Manchester: Manchester University Press, 56-78.

Searle, J. (1969). Speech Acts: An Essay in the Philosophy of language. Cambridge: Cambridge University Press.

Searle, J. R. (1979). Expression and Meaning. Studies in the Theory of Speech Acts. Cambridge: Cambridge University Press.

Searle, J. R. (1994). How Performatives Work. In: Harnish, R. M. (ed.), Basic Topics in the Philosophy of Language. London: Harvester Wheatsheaf, 75-95.

Searle, J. R. (1996a). What is a Speech Act? In: Martinich, A. P. (ed.), The Philosophy of Language. Oxford: Oxford University Press, 130-140.

Searle, J. R. (1996b). Indirect Speech Acts. In: Martinich, A. P. (ed.), The Philosophy of Language. Oxford: Oxford University Press, 168-182.

Smith, R. (1995). Julian's Gods. Religion and Philosophy in the Thought and Action of Julian the Apostate. London and New York: Routledge.

Tougher, S. (2007). Julian the Apostate (Debates and Documents in Ancient History). Edinburgh: Edinburgh University Press.

Wright, W. C. (1998). The works of the emperor Julian. London: Loeb Clas. Libr.

Winter, E. (1977). A clause relational approach to English texts: a Study of some predictive items in written discourse. Instructional Science 6/1: 192. 